\section{Initial Growth of Rosebay Rhododendron Seedlings as Influenced by Day and Night Temperatures}

\author{
Mark C. Starrett', Frank A. Blazich ${ }^{2}$, and Stuart L. Warren ${ }^{3}$ \\ Department of Horticultural Science, Box 7609, North Carolina State \\ University, Raleigh, NC 27695-7609
}

Additional index words. Rhododendron maximum, native plants, optimum temperature, Ericaceae

\begin{abstract}
Rosebay rhododendron (Rhododendron maximum L.) seedlings were grown in controlled-environment chambers for 14 weeks under long (9-hour) days at 18, 22, 26, or $30 \mathrm{C}$ in factorial combination with 15 -hour nights at $14,18,22$, or $26 \mathrm{C}$. Total dry-matter production was lowest for $18 \mathrm{C}$ days and highest for $26 \mathrm{C}$ days. A similar response occurred for top, leaf, root, and stem dry weights. Nights at $22 \mathrm{C}$ maximized total plant, top, leaf, and stem dry weights. The optimum day/night cycle for dry-matter production was 26/22C. Leaf area was optimum with $18 \mathrm{C}$ nights. Leaf weight ratio (leaf dry weight: total plant dry weight) increased with an increase in night temperature to a maximum at $22 \mathrm{C}$. Root weight ratio (root dry weight : total plant dry weight) decreased with an increase in night temperature to a minimum at $22 \mathrm{C}$. Stem weight ratio (stem dry weight : total plant dry weight) and shoot : root ratio (top dry weight : root dry weight) were not influenced significantly by day or night temperature. A day/night cycle of $26 / 22 \mathrm{C}$ seems to be optimal for producing-salable plants.
\end{abstract}

Rosebay rhododendron is a well-known, native evergreen rhododendron in eastern North America. It ranges from Qué., Canada, south through New England to its optimal habitat in the Appalachian Mountains of North Carolina (Leach, 1961). Mature height depends on the climate and varies from $1 \mathrm{~m}$ (a shrub) in the colder northeast to $12 \mathrm{~m}$ (a tree) in the southeast. Under cultivation, this species normally reaches a height of 4 to $5 \mathrm{~m}$. Blooms range from pink to white and are produced during July.

New shoot growth of rosebay rhododendron often reduces the impact of flowering. However, the size, texture, and late bloom period of this plant make it highly desirable as a woodland shrub for large gardens, parks, and estates (Leach, 1961). Rosebay rhododendron is well suited for low light and flourishes in shaded areas where other species of similar habit will not.

Heightened interest in native plants has

\footnotetext{
Received for publication 8 Sept. 1992. Accepted for publication 8 Feb. 1993. This research was funded by the North Carolina Agricultural Research Service (NCARS), Raleigh, NC 27695-7643. Use of trade names in this publication does not imply endorsement by NCARS of products named nor criticism of similar ones not mentioned. We acknowledge the assistance of Southeastern Plant Environment Laboratory (Phytotron) staff, Juan R. Acedo, and William M. Reece. From a thesis submitted by M.C.S. in partial fulfillment of the MS degree requirements. The cost of publishing this paper was defrayed in part by the payment of page charges. Under postal regulations, this paper therefore must be hereby marked advertisement solely to indicate this fact.

'Graduate Teaching Assistant.

${ }^{2}$ Professor.

${ }^{3}$ Associate Professor.
}

growth. Therefore, the objective of this study was to examine the effects of selected day/ night temperatures on initial vegetative growth of rosebay rhododendron seedlings under longday conditions.

Two-year-old seedlings, propagated from open-pollinated rosebay rhododendron seed collected in Polk County, Tenn., were purchased from Apalachee Nursery, Turtletown, Tenn., on 14 June 1991. At the time of purchase, 12- to 20-cm-tall seedlings were growing in wood flats with a pine bark medium. In the nursery, plants were grown under ambient conditions from spring through fall and overwintered in a white polyethylene-covered, nonheated quonset frame house.

Seedlings were transported to Raleigh and, on 17 June 1991, they were removed from the flats and transplanted individually into 1-liter, black, plastic containers filled with a medium of arcillite [Turface; AIMCOR, Deerfield, Ill.], a calcined clay that allowed easy recovery of intact root systems at harvest (Hiller and Keller, 1979). On 18 June, transplants were drenched with methyl 1-(butylcarbamoyl)2-benzimidazolecarbamate [benomyl (Benlate $50 \mathrm{DF})]$ at a rate of $0.55 \mathrm{~g} \cdot$ liter $^{-1}$.

Two weeks after being transplanted, seedlings were fertilized weekly with $180 \mathrm{mg}$ N/liter from a $15 \mathrm{~N}-20 \mathrm{P}-4 \mathrm{~K}$ water-soluble fertilizer [Rhododendron Special; Grace-Sierra, Fogelsville, $\mathrm{Pa}$.)] containing (in mg.liter ${ }^{-1}$ ) $200 \mathrm{CaCl}_{2}$ and $75 \mathrm{MgSO}_{4}$. Fertilization was increased to twice weekly starting at 5 weeks after transplanting. From the time of transport to Raleigh, plants were grown under natural photoperiod and irradiance in a greenhouse maintained at a day/night cycle of 30/22 $\pm 3 \mathrm{C}$.

On 5 Aug., plants were transferred to the Southeastern Plant Environment Laboratory (Phytotron). Various temperature regimes were initiated the following day using controlledenvironment A-chambers (Downs and Thomas, 1983). The study was a $4 \times 4$ factorial in a completely randomized design using nine single-plant replications per temperature combination. The two main factors were four day temperatures $(18,22,26$, and $30 \mathrm{C})$ in factorial combination with four night temperatures (14, 18, 22, and 26C). Day temperatures were maintained for $9 \mathrm{~h} \cdot \mathrm{day}^{-1}$ and coincided with the daily high irradiance period. Temperatures were maintained within $\pm 0.25 \mathrm{C}$ of the set point. Plants were moved between chambers at 8:00 AM and 5:00 PM daily to maintain appropriate day/night temperatures. Relative humidity was $>70 \%$. Carbon dioxide concentration was 300 to $400 \mu \mathrm{l} \cdot$ liter $^{-1}$.

During the 9-h high-irradiance period, coolwhite fluorescent and incandescent lamps provided a photosynthetic photon flux (PPF) of $642 \mu \mathrm{mol} \cdot \mathrm{m}^{-2} \cdot \mathrm{s}^{-1}$ plus photomorphogenic radiation $(\mathrm{PR})$ of $8 \mathrm{~W} \cdot \mathrm{m}^{-2}$. Incandescent lamps providing a PPF of $44 \mu \mathrm{mol} \cdot \mathrm{m}^{-2} \cdot \mathrm{s}^{-1}$ plus PR of $6.7 \mathrm{~W} \cdot \mathrm{m}^{-2}$ were used to interrupt the dark periods between 11:00 PM and 2:00 AM, a practice resulting in long days and which maximized vegetative growth in previous rhododendron studies (Barba and Pokorny, 1975; Barrick and Sanderson, 1973; Doorenbos, 1955; Malek, et al., 1989; Pettersen, 1972). 
Initially, plants were fertilized twice weekly (Tuesday and Friday) with the standard Phytotron nutrient solution (Downs and Thomas, 1983). Beginning during week 3, fertilization was increased to three times weekly (Monday, Wednesday, and Friday). Plants were watered with deionized water on the remaining days. After 3 weeks, symptoms characteristic of Fe deficiency were observed and all plants were treated with $0.3 \mathrm{~g} \mathrm{FeSO}_{4} /$ liter sprayed to runoff. Similar applications were administered on 29 Oct. and 6 Nov. 1991.

The study ended after 14 weeks. Plants were harvested and total leaf area was measured with a leaf area meter (model LI-3100; LI-COR, Lincoln, Neb.). Plants were divided into leaves, stems, and roots; dried at $70 \mathrm{C}$ for $72 \mathrm{~h}$; and weighed. Tissue dry weight data were used to generate the following: total plant dry weight (sum of leaf, stem, and root dry weight); top dry weight (sum of leaf and stem dry weight); shoot : root ratio (top dry weight: root dry weight); leaf: root ratio (leaf dry weight: root dry weight); leaf weight ratio (leaf dry weight: total plant dry weight); stem weight ratio (stem dry weight: total plant dry weight); root weight ratio (root dry weight : total plant dry weight); leaf area ratio (total leaf area: total plant dry weight); and specific leaf area (total leaf area : leaf dry weight). Data were subjected to general linear modeling procedures and regression analysis.

Dry-matter production was influenced by day and night temperatures (Table 1). There were, however, no significant interactions between day and night temperatures for any reported measurements or significant linear responses to the temperatures investigated. Total plant dry weight (Fig. 1A) was lowest at $18 \mathrm{C}$ days and increased to a maximum at 26C. A similar response occurred for top, leaf, root, and stem dry weights (Fig. 1A). Nights of $22 \mathrm{C}$ maximized total plant, top, leaf, and stem dry weight (Fig. 1B).

Leaf area (Fig. 2A) and specific leaf area (Fig. 2B) were greatest at $18 \mathrm{C}$ nights. There were no significant day temperature effects for

Table 1. Growth responses of rosebay rhododendron seedlings to selected day/night temperatures.

\begin{tabular}{lcccc}
\hline \hline Growth & \multicolumn{4}{c}{ Variable $^{\text {z,y }}$} \\
\cline { 2 - 5 } measurement & $\mathrm{D}$ & $\mathrm{DQ}$ & $\mathrm{N}$ & $\mathrm{NQ}$ \\
\hline Dry wt & & & & \\
$\quad$ Total plant & 0.03 & 0.10 & 0.07 & $\mathrm{NS}$ \\
-Top & 0.02 & 0.07 & 0.01 & 0.08 \\
Leaf & 0.06 & 0.10 & 0.02 & 0.09 \\
Stem & 0.01 & 0.03 & 0.02 & 0.07 \\
Root & 0.08 & NS & NS & NS \\
Leaf area & NS & NS & 0.01 & 0.02 \\
Shoot : root ratio & NS & NS & NS & NS \\
Leaf area ratio & NS & NS & 0.01 & 0.01 \\
Leaf weight ratio & NS & NS & 0.03 & 0.08 \\
Stem weight ratio & NS & NS & NS & NS \\
Root weight ratio & NS & NS & 0.02 & 0.01 \\
Specific leaf area & NS & NS & 0.01 & 0.02 \\
\hline
\end{tabular}

${ }^{2} \mathrm{D}=$ day temperature, $\mathrm{DQ}=$ day temperature (quadratic), $\mathrm{N}=$ night temperature, $\mathrm{NQ}=$ night temperature (quadratic).

${ }^{y}$ Nonsignificant (NS) or significant at the level indicated; linear components for day and night temperatures were nonsignificant.
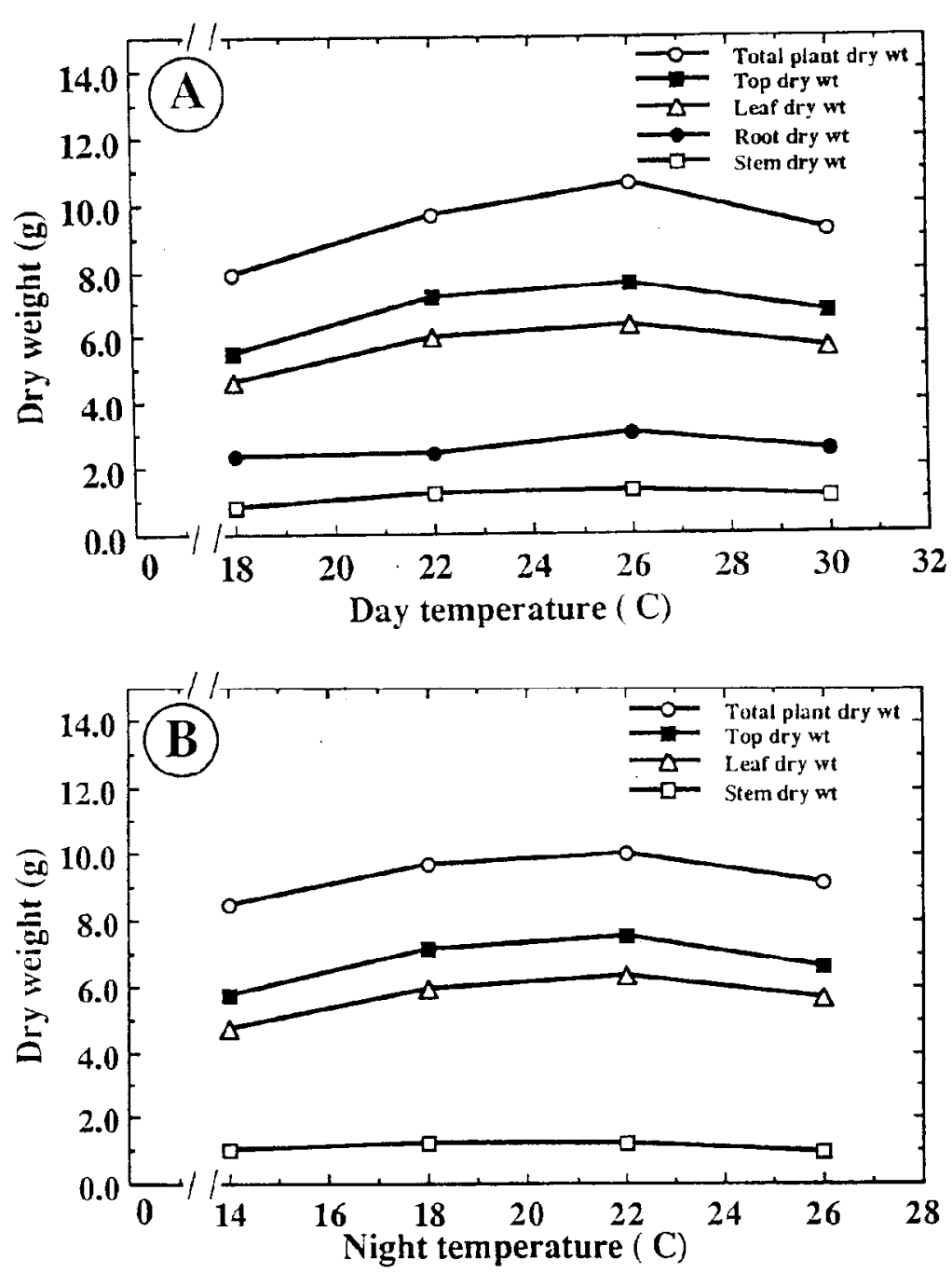

Fig. 1. Effects of selected (A) day and (B) night temperatures on dry weight during initial growth of rosebay rhododendron seedlings. Each symbol is the mean of nine observations.

either leaf area or specific leaf area (Table 1). At a $14 \mathrm{C}$ night, leaf area was $33 \%$ less than that at $18 \mathrm{C}$. The leaf weight ratio was consistently higher than root weight ratio across night temperatures (Fig. 2C). Leaves represented $56 \%$ to $63 \%$ of total plant dry weight across all night temperatures. With nights between 14 and $22 \mathrm{C}$, leaf dry weight increased with temperature at the expense of roots $\left[R^{2}=(-0.93)\right]$. Leaf area ratio was maximum between 18 and 22C nights (Fig. 2D); maximum leaf area followed closely (Fig. 2A).

Increasing day temperature from 18 to $26 \mathrm{C}$ increased all dry-matter categories, with lower values at 30C (Fig. 1A). Dry weights across night temperatures showed a response similar to that for day temperatures. Dry matter increased from 14 to $22 \mathrm{C}$ for all categories (Fig. 1B) except roots. Temperatures $>22 \mathrm{C}$ resulted in a decrease in total plant, top, leaf, and stem dry weight (roots were not significantly affected by night temperature). Presumably, higher night temperature results in greater respiratory carbohydrate loss and reduced dry weight accumulation (Deal et al., 1990; Hussey, 1965; Kramer and Kozlowski, 1979).

Across night temperatures, leaf weight ratio was always higher than root weight ratios, a result indicating a preferential distribution of dry matter to the leaves during initial seedling growth (Fig. 2C). Malek et al. noted a similar response in flame azalea (1992a) and mountain laurel (Kalmia latifolia L.) (1992b). In rosebay rhododendron, leaf weight ratio increases were accompanied by root weight ratio decreases, a result demonstrating a shift in competitive partitioning between these two organs during seedling growth across night temperatures. Assimilate partitioning to stems was not affected by changes in day or night temperatures.

Leaf area was greatest at $18 \mathrm{C}$ nights (Fig. 2A). Similarly, maximum total plant dry weight occurred at a moderately low night temperature (Fig. 1B). In general, dry-matter production in the vegetative stage is strongly associated with leaf area development (Dale, 1964).

Specific leaf area is a morphological index of leaf expansion that also can be used as an indirect measure of leaf thickness, where a high ratio corresponds to a thin leaf (Friend et al., 1965). Data for specific rosebay rhododendron leaf area (Fig. 2B) indicated that leaves were thinner and larger at $18 \mathrm{C}$ nights but thickened and became smaller as nights increased to 26C (supported by data in Fig. 2A 

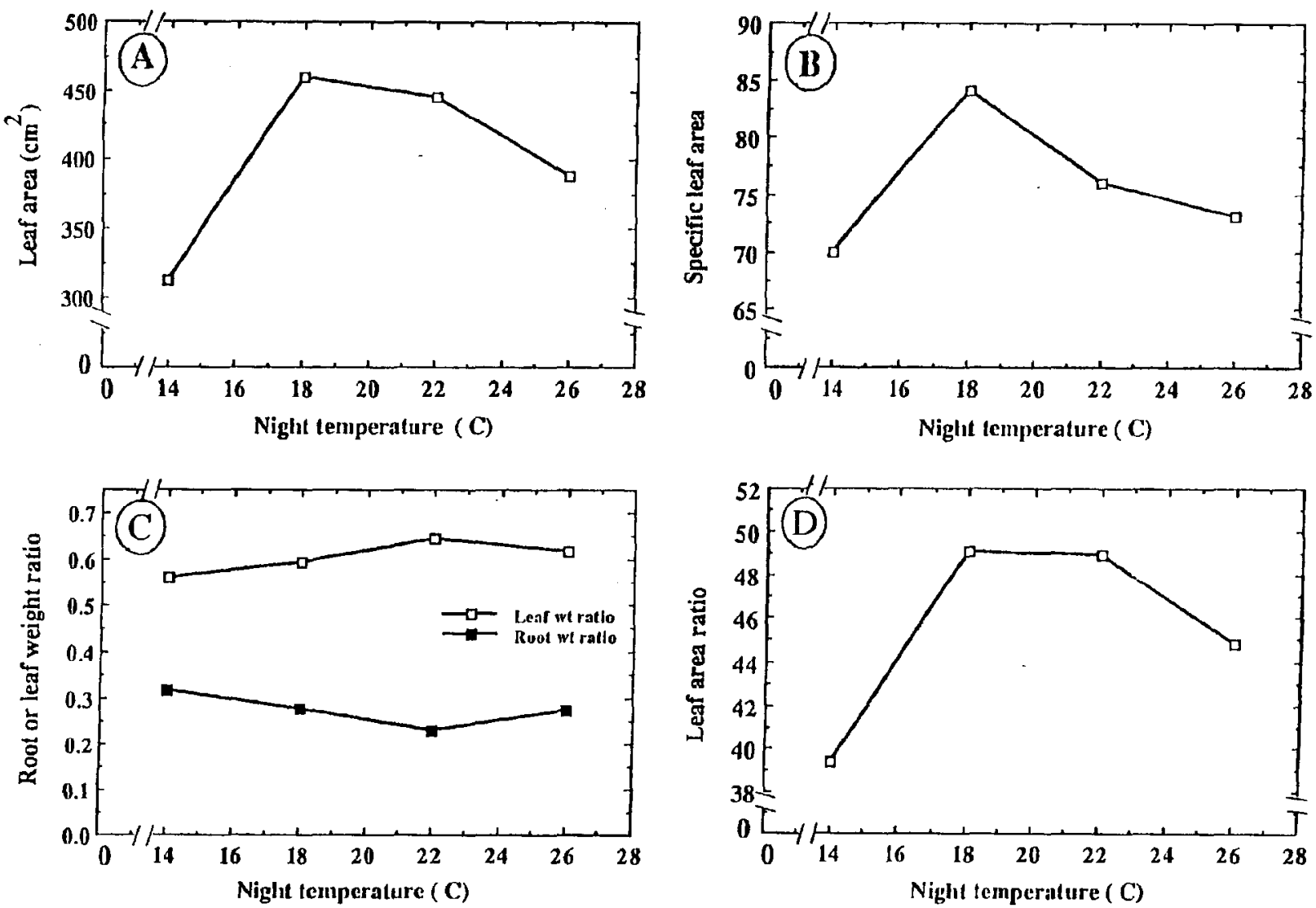

Fig. 2. Effects of night temperature (averaged over all day temperatures) on initial growth of rosebay rhododendron seedlings: (A) leaf area, (B) specific leaf area,

(C) root or leaf weight ratio, (D) leal area ratio. Each symbol is the mean of 36 observations.

and by our observations). Malek et al. (1992a) noted a similar response in flame azalea seedlings. Smaller-leaves at elevated night temperatures could be related to higher respiration rates, resulting in less available carbohydrates for leaf expansion.

The optimum day/night temperature for rosebay rhododendron dry-matter production was $26 / 22 \mathrm{C}$. This is contrary to reports of a lack of optimal thermoperiodicity relative to total plant dry weight in flame azalea (Malek et al., 1992a) and mountain laurel (Malek et al., 1992b) seedlings. Our findings indicate that producing rosebay rhododendron under long days using a day/night cycle of $26 / 22 \mathrm{C}$ may increase seedling development rate and result in a plant that more quickly attains a salable size.

\section{Literature Cited}

Barba, R.C. and F.A. Pokorny. 1975. Influence of photoperiod on the propagation of two rhododendron cultivars. J. Hort. Sci. 50:55-59.

Barrick, W.E. and K.C. Sanderson. 1973. Influence of photoperiod, temperature, and node position on vegetative shoot growth of greenhouse azaleas, Rhododendron cv. J. Amer. Soc. Hort. Sci. 98:331-334.

Bir, R.E., J.E. Shelton, V.P. Bonaminio, J.R. Baker, and R.K. Jones. 1981. Growing native ornamentals from cutbacks in western North Carolina. In: V.P. Bonaminio (ed.). North Carolina nursery crops production manual. North Carolina Agr. Ext. Serv., Raleigh.
Bowers, C.G. 1960. Rhododendrons and azaleas. Macmillan, New York

Dale, J.E. 1964. Some effects of alternating temperature on the growth of French bean plants. Ann. Bot. (new series) 28:127-135.

Deal, D.L., J.C. Raulston, and L.E. Hinesley. 1990. Leaf color retention, dark respiration, and growth of red-leafed Japanese maples under high night temperatures. J. Amer. Soc. Hort. Sci. 115: 135140.

Doorenbos, J. 1955. Shortening the breeding cycle of rhododendron. Euphytica 4:141-146.

Downs, R.J. and J.F. Thomas. 1983. Phytotron procedural manual for controlled environment research at the Southeastern Plant Environment Laboratoy. North Carolina Agr. Res. Serv. Tech. Bul. 244 (revised).

Friend, D.J.C., V.A. Helson, and J.E. Fisher. 1965. Changes in the leaf area ratio during growth of Marquis wheat, as affected by temperature and light intensity. Can. J. Bot. 43:15-28.

Haroon, M., R.C. Long, and J.A. Weybrew. 1972. Effects of day/night temperature on factors associated with growth of Nicotiana tabacum L. in controlled environments. Agron. J. 64:509-515.

Hellmers, H. 1966. Temperature action and interaction of temperature regimes in the growth of red fir seedlings. Forest Sci. 12:90-96.

Hiller, L,K. and K.C. Keller. 1979. Potato growth responses in arcillite and sand. HortScience 14:534-536.

Hinesley, L.E. 1981. Initial growth of Fraser fir seedlings at different day/night temperatures. Forest Sci, 27:545-550.

Hussey, G. 1965. Growth and development in the young tomato. III. The effect of night and day temperatures on vegetative growth. J. Expt. Bot. 16:373-385.

Kramer, P.J. and T.T. Kozlowski. 1979. Physiology of woody plants. Academic, New York.

Leach, D.G. 1961. Rhododendrons of the world and how to grow them. Charles Scribner's Sons, New York,

Lipscomb, M.V. and E.T. Nilsen. 1990. Environmental and physiological factors influencing the natural distribution of evergreen and deciduous ericaceous shrubs on northeast and southwest slopes of the southern Appalachian Mountains. I. Irradiance tolerance. Amer. J. Bot. 77:108115.

Malek, A.A., F.A. Blazich, S.L. Warren, and J.E. Shelton. 1989. Growth response of flame azalea as influenced by temperature and photoperiod. Proc. Southern Nurserymen's Assn. Res. Conf., 34th Annu. Rpt. p. 47-48.

Matek, A.A., F.A. Blazich, S.L. Warren, and J.E. Shelton. 1992a. Initial growth of seedlings of flame azalea in response to day/night temperature. J. Amer. Soc. Hort. Sci. 117:216-219,

Malek, A.A., F.A. Blazich, S.L. Warren, and J.E. Shelton. 1992b. Initial growth of seedlings of mountain laurel as influenced by day/night temperature. J. Amer. Soc. Hort. Sci. 117:736-739.

Nilsen, E.T. 1987. The influence of temperature and water relations on leaf movements in Rhododendron maximum. Plant Physiol. 83:607-612.

Pettersen, H. 1972. The effect of temperature and daylength on shoot growth and bud formation in azaleas. J. Amer. Soc. Hort. Sci. 97:17-24.

Skinner, H.T. 1939. Factors affecting shoot growth and flower bud formation in rhododendrons and azaleas. Proc. Amer. Soc. Hort. Sci. 37:10071011. 